\title{
KREATIVITAS MENULIS DAN MENGAPRESIASI PUISI SISWA SMP NEGERI MAUBELI
}

\author{
Metropoly Merlin J. Liubana ${ }^{1)}$, Hesni Neno ${ }^{2)}$ \\ Pendidikan Bahasa dan Sastra Indonesia, Fakultas Ilmu Pendidikan \\ Universitas Timor, Indonesia ${ }^{1)}$, Pendidikan Bahasa Inggris, Fakultas Ilmu Pendidikan \\ Universitas Timor, Indonesia ${ }^{2)}$
}

Pos-el: $\underline{\text { mmerlin2007@gmail.com }}{ }^{1)}$, nenohesny@yahoo.co.id ${ }^{2)}$

\begin{tabular}{|l|l|l|}
\hline Dikirim: 17, 07, 2020 & Direvisi: 31, 08, 2020 & Diterbitkan: 31, 08, 2020
\end{tabular}

\begin{abstract}
Abstrak
Kreativitas dalam pembelajaran menulis dan mengapresiasi puisi ditunjang dengan pengetahuan dan latihan secara praktik, intens, dan bervariasi. Salah satu kegiatan yang dapat dilakukan untuk memenuhi hal tersebut adalah dengan cara melakukan tindakan sebagai pengabdi pada siswa SMP Negeri Maubeli. Metode yang digunakan adalah ceramah, diskusi, penugasan, praktik latihan menulis dengan teknik mengamati objek secara langsung, dan mengapresiasi puisi dengan cara membaca. Hasil yang diperoleh berupa penilaian menulis puisi dari 38 siswa mencapai nilai $72 \%$, dengan jumlah skor keseluruhan 2728 , dan termasuk dalam kategori baik. Hasil dari penilaian membaca puisi mencapai nilai $74 \%$, dengan jumlah skor keseluruhan 2830, dan termasuk dalam kategori baik. Sedangkan hasil menulis dan membaca puisi tersebut diakumulasi menjadi rerata skor $71.5 \%$ dari jumlah keseluruhan yakni 2713.5. Tingkat penguasaan siswa kelas VIII SMP Negeri Maubeli dalam menulis dan membaca puisi berinterval 80-100, dengan kategori baik sekali sebanyak 16 siswa sehingga persentase tingkat penguasaan hanya mencapai 42.10\%; berinterval 70-79 dengan kategori baik sebanyak 11 siswa dengan persentase tingkat penguasaan mencapai $28.94 \%$; berinterval 60-69 berkategori cukup baik sebanyak 5 siswa, dengan persentase tingkat penguasaan mencapai $13.15 \%$; dan berinterval 0-59 berkategori kurang baik sebanyak 6 siswa, sehingga persentase tingkat penguasaan mencapai $15.78 \%$.
\end{abstract}

Kata Kunci: pelatihan menulis, mengapresiasi, puisi.

\begin{abstract}
The creativity in writing and appreciating poetry has to be supported with knowledge and a number of practical, intense, and varied exercises. For the sake of sharing knowledge and providing such kind of exercises the writer held a community service towards students in SMP Negeri Maubeli. The methods used are lecturing, discussing, tasking, exercising and a direct observation simultaneously towards objects and appreciating poetry through reading aloud. The scoring of the students' writing is $72 \%$ from 38 students with the total score of 2728 , which is categorized good. The scoring of the reading poetry is $74 \%$, with the total score of 2830 , which is categorized good. The mean resulting from accumulating students' writing and reading poetry scores is $71.5 \%$ with the total score of 2713.5. The mastery level of students grade VIII in SMP Negeri Maubeli in writing and reading poetry is varied. It is $42.10 \%$ of students categorized very good because only 16 students gained 80-100. 28.94\% students are categorized good because there are 11 students gained 70-79. $13.15 \%$ students are categorized enough since there are 5 students gained $60-69$. The last is $15.78 \%$ students are categorized poor as 6 students gained 0-59.
\end{abstract}

Keyword: training writing, appreciating, poetry.

\section{PENDAHULUAN}


Kegiatan menulis puisi dapat dilakukan dengan mengembangkan imajinasi dan emosi secara kreatif dan efektif untuk menghasilkan sebuah puisi. Menulis puisi seperti menawarkan derita batin yang telah lama terpenjara dengan menguntai diksi atau kalimat yang menarik dan secara emotif. Hal itu dilakukan bukan saja untuk mengekspresikan diri sendiri, namun sebagai bentuk pengekspresian kondisi manusia sebagai homo ludens (makluk bermain) dan homo fabulans (makluk bersastra).

Menulis puisi dapat dilakukan dengan berbagai teknik terutama pada penulis pemula seperti siswa SMP. Sebagai pemula, siswa-siswa membutuhkan kemampuan guru untuk membangun kreatifitas dalam menulis dan mengapresiasikan karya puisi. Kemampuan guru tidak hanya memberi pengetahuan yang lazim dilakukan seperti biasanya, dengan berdiri di depan kelas kemudian menjelaskan materi kemudian siswa disuruh praktik. Tetapi harus bervariasi agar siswa termotivasi dan dapat berkreasi dalam berkarya. Untuk melatih siswa berkreasi dalam menulis karya puisi, guru diharapkan menerapkan berbagi teknik. Teknik dalam menulis puisi sangat beragam. Di antaranya: teknik mengurai nama sendiri; berdasarkan pengalaman; berdasarkan cerita tokoh, sejarah, mitologi; dan berdasarkan pengamatan objek secara langsung. Demikian pula dengan kegiatan mengapresiasi puisi dapat dilakukan dalam bentuk pembacaan sebagai kelanjutan dari hasil penulisan kreatif siswa tersebut.

Apresiasi adalah mengenal, memahami, menikmati dan menilai. Menurut Waluyo (2002: 44) apresiasi biasanya dikaitkan dengan seni. Apresiasi puisi berkaitan dengan kegiatan yang ada sangkut pautnya dengan puisi, yaitu mendengar atau membaca puisi dengan penghayatan yang sungguh-sungguh. Dalam penerapannya apresiasi memerlukan aktivitas, kreativitas, dan motivasi dalam menunjukkan kemampuan atau potensi seseorang karena apresiasi merupakan sebuah proses. Hal tersebut senada dengan pendapat Abdul Rozak Zaidan (2001: 21) yang menyatakan bahwa apresiasi sastra itu berlangsung dalam suatu proses yang mencakup pemahaman, penikmatan, dan penghayatan. Selain itu pendekatan proses efektif dalam meningkatkan pembelajaran Apresiasi Puisi (Arief \& Sampara, 2019). Ristian (2020) juga mengatakan bahwa Kreativitas verbal bisa kembangkan melalui kreativitas dalam menulis teks puisi.

Kegiatan apresiasi lebih dekat dengan pengembangan keterampilan berbahasa, karena hakikat apresiasi adalah upaya memahami, menikmati, menghayati, dan menghargai suatu karya sastra (Muchlisoh, 2003: 57). Dapat disimpulkan bahwa apresiasi puisi atau apresiasi sastra pada mumnya merupakan salah satu bentuk penghargaan terhadap karya sastra, misalnya membaca puisi. Pembelajaran apresiasi puisi di sekolah bukan hanya sekedar peserta didik terampil membaca puisi, melainkan pada saat tahap penjelajahan mereka perlu memahami, menafsirkan, dan menerapkan nilai-nilai pendidikan yang ada di dalam isi puisi terhadap kehidupan di masyarakat.

Salah satu model pembelajaran lingkungan yang dapat dilakukan di sekitar sekolah adalah dengan mengamati objek secara langsung tanpa mengeluarkan biaya yang banyak. Di samping itu, waktu yang dibutuhkan sangat efisien. Lingkungan sebagai media pengajaran pada dasarnya memvisualkan fakta gagasan, kejadian, peristiwa dalam bentuk tiruan dari keadaan sebenarnya untuk dibahas di kelas dalam membantu proses belajar mengajar. Di lain pihak, guru dan siswa dapat mempelajari keadaan sebenarnya di luar kelas dengan menghadapkan para siswa kepada lingkungan yang aktual untuk dipelajari, diamati dalam 
hubungannya dengan proses belajar mengajar. Cara ini lebih bermakna disebabkan siswa dihadapkan pada peristiwa dan keadaan yang sebenarnya secara alami, lebih aktual, dan dapat dipertanggungjawabkan. Keuntungan yang dapat diperoleh dari kegiatan mengamati lingkungan sekitar adalah kegiatan belajar lebih menarik dan tidak membosankan.

Kegiatan menulis secara kreatif dengan mengamati objek secara langsung juga dapat mempermudah siswa dalam melatih imajinasi mereka, dan menuangkan pemikirannyanya dalam bentuk tulisan, kemudian mampu mengapresiasikan karya mereka sendiri dengan penuh penghayatan dan pemahaman yang tinggi. Kegiatan menulis dan mengapresiasikan karya puisi, dilakukan dengan tahapan: mengamati objek secara langsung di luar kelas; menghayati; dan menuangkan ide dalam tulisan; kemudian membaca dengan penghayatan yang mendalam.

\section{METODE}

Pelaksanaan kegiatan pengabdian ini, bertempat di SMP Negeri Maubeli Kefamenanu yang berlangsung dari bulan Agustus sampai Oktober 2019. Kegiatan ini dilaksanakan dalam beberapa tahap yakni, survei dan observasi; pelaksanaan berupa teori dan praktik; dan evaluasi. Dalam tahap survei dan observasi, dilakukan koordinasi dengan mitra kegiatan untuk kesepakatan, dan mengobservasi keadaan pembelajaran di kelas untuk pelaksanaan kegiatan selanjutnya. Tahap berikut yaitu pelaksanaan kegiatan secara teroretis dan praktik yang dilakukan selama dua hari. Hari pertama penerapan materi di kelas dengan metode ceramah, dan melakukan praktik mengamati objek di luar kelas, kemudian menulis puisi. Hari kedua mengapresiasi puisi dengan membaca dan menghayati secara mendalam, kemudian memberi umpan balik kepada siswa atas hasil kerja mereka. Tahap terakhir yaitu evaluasi, penulis merangkum semua hasil kegiatan dalam bentuk laporan, terutama hasil kerja siswa yang telah diberi penilaian.

\section{HASIL DAN PEMBAHASAN}

Kegiatan pengabdian dengan judul Kreativitas Menulis dan Mengapresiasi Puisi Siswa SMP Negeri Maubeli, dilaksanakan tepat waktu dan berlangsung dengan lancar. Diawali dengan tahap survei dan observasi yang dilaksanakan pada tanggal 7 September 2019. Pada tahap ini penulis melakukan koordinasi dengan mitra kegiatan yakni pihak sekolah untuk menetapkan waktu pelaksanaan. Selain itu melakukan observasi berkaitan dengan pembelajaran puisi. Hal-hal yang menjadi fokus pengamatan adalah kurikulum, materi pembelajaran, keaktifan siswa terhadap pembelajaran di kelas, jumlah siswa, guru pendamping, fasilitas pembelajaran baik media, sarana prasarana, dan objek lingkungan luar kelas. Semua hasil observasi tersebut dijadikan catatan pertimbangan utama dalam pelaksanaan kegiatan pengabdian yang dijadwalkan.

Pertemuan secara tatap muka dengan metode ceramah dan latihan atau praktik untuk mengapresiasi puisi, mulai dari tahap penulisan dengan proses pengamatan objek, pemilihan judul, penyusunan kata-kata menjadi sebuah karya puisi, hingga mengapresiasikan hasil tulisan dengan membacakan puisi. Kegiatan ini dilaksanakan selama dua hari yaitu pada Jumat, 6 September 2019 dan Saptu 8 September 2019 dari pukul 09.00 - 12.00 WITA. Peserta kegiatan berjumlah 38 siswa, dengan didampingi 2 guru Bahasa Indonesia dan lokasi pelaksanaan kegiatan di Ruang kelas IX, serta di lingkungan SMP Negeri Maubeli.

Pelaksanaan kegiatan pengabdian dilaksanakan oleh 2 pengabdi. dengan pokok bahasan yang disampaikan yaitu: (1) pengetahuan mengenai keterampilan berbahasa menulis 
dan apresiasi sastra berupa puisi; (2) pengetahuan mengenai tahapan-tahapan dalam proses pemikiran kreatif untuk menulis puisi; (3) pentingnya berlatih menulis secara terus-menerus dan mengembangkan karya sastra berupa puisi dengan berbagai teknik menulis; (4) mengajak siswa mengamati objek secara langsung di luar kelas dengan bebas; dan (5) membimbing siswa menulis puisi dari hasil pengamatan objek; (6) mengapresiasikan hasil tulisan berupa pembacaan puisi.

Kegiatan hari pertama diawali dengan pembukaan kegiatan oleh Wakil Kepala SMP Negeri Maubeli, dilanjutkan dengan pemberian materi menulis dan mengapresiasi puisi selama 40 menit. Selanjutnya diskusi yang dilakukan antara pemateri dengan siswa/peserta selama 20 menit, kemudian pembagian kelompok dengan empat orang pendamping, dua orang pengabdi dan dua orang dari guru Bahasa Indonesia SMP Negeri Maubeli. Masingmasing pendamping membawa peserta keluar ruangan dan berbaur pada lingkungan sekolah untuk mendapatkan objek sebagai bahan pengamatan, semua peserta dalam pengawasan pendamping. Setelah semua peserta mendapatkan objek pengamatan, peserta dipersilahkan untuk mengamati objek selama 20 menit dan setelah itu kembali memasuki ruangan. Kegiatan selanjutnya, seluruh peserta menuangkan hasil pengamatan ke dalam sebuah tulisan berupa puisi. Waktu menulis puisi diberikan selama 40 menit. Penulisan puisi memperhatikan penempatan judul, diksi, tipografi, amanat, seuai dengan materi dan diskusi sebelumnya.

Kegiatan hari kedua dilanjutkan dengan memberikan penjelasan mengenai cara mengaprsiasi puisi disertai pemberian contoh pembacaan puisi. Pembacaan puisi yang dilakukan memperhatikan: ketetapan pengucapan (aritikulasi, intonasi, bunyi, irama, gaya, dan nada); penafsiran (mengandung makna); dan penghayatan yang mendalam. Selanjutnya peserta diberi kesempatan untuk latihan selama 10 menit dengan dibimbing oleh masingmasing pendamping. Setelah latihan, siswa melaksanakan proses apresiasi di depan kelas dengan cara membaca puisi hasil karya mereka sendiri. Sebanyak 38 puisi yang dibacakan/diapresiasikan oleh masing-masing siswa. Setiap siswa diberi hadiah berupa dua bulpoin dan satu buku tulis, sedangkan yang menjadi juara satu, dua, dan tiga diberi hadiah berupa buku kumpulan puisi milik pengabdi.

Hasil penilaian menulis dan mengapresiasi puisi siswa dipaparkan dalam bentuk tabel yaitu: tabel 1 menjelaskan tentang hasil penilaian menulis puisi; tabel 2 menjelaskan tentang hasil penilaian membaca puisi; tabel 3 menjelaskan tentang hasil akumulasi penilaian menulis dan membaca puisi; tabel 4 menjelaskan tentang tingkat penguasaan siswa dalam menulis dan membaca puisi.

Tabel 1. Hasil Penilaian Menulis Puisi

\begin{tabular}{|c|c|c|c|c|c|c|c|c|}
\hline \multirow[b]{3}{*}{ NO } & \multirow{3}{*}{$\begin{array}{l}\text { Kode } \\
\text { Nama } \\
\text { Siswa }\end{array}$} & \multicolumn{7}{|c|}{ Skor Penilaian } \\
\hline & & Judul & Diksi & Tipografi & Citraan & Amanat & Jumlah & Nilai \\
\hline & & $\begin{array}{c}\text { Skor } \\
\text { maks. } \\
5 \%\end{array}$ & $\begin{array}{c}\text { Skor } \\
\text { maks. } \\
5 \%\end{array}$ & $\begin{array}{c}\text { Skor } \\
\text { maks. } \\
5 \%\end{array}$ & $\begin{array}{c}\text { Skor } \\
\text { maks. } \\
5 \%\end{array}$ & $\begin{array}{c}\text { Skor } \\
\text { maks. } \\
5 \%\end{array}$ & $\begin{array}{c}\text { Skor maks. } \\
25 \%\end{array}$ & $\begin{array}{l}\text { Skor } \\
\text { maks. } \\
100 \%\end{array}$ \\
\hline 1 & MWT & 4 & 5 & 4 & 4 & 4 & 21 & 84 \\
\hline 2 & WDB & 4 & 4 & 4 & 4 & 4 & 20 & 80 \\
\hline 3 & YEL & 3 & 3 & 5 & 4 & 4 & 19 & 76 \\
\hline 4 & $\mathrm{EE}$ & 4 & 3 & 3 & 3 & 4 & 17 & 68 \\
\hline 5 & $\mathrm{~N}$ & 3 & 3 & 4 & 4 & 4 & 18 & 72 \\
\hline 6 & MVO & 4 & 4 & 3 & 4 & 4 & 19 & 76 \\
\hline 7 & $\mathrm{AF}$ & 3 & 3 & 3 & 4 & 3 & 16 & 64 \\
\hline 8 & DSD & 3 & 4 & 4 & 4 & 3 & 18 & 72 \\
\hline
\end{tabular}




\begin{tabular}{|c|c|c|c|c|c|c|c|c|}
\hline 9 & CIKA & 4 & 4 & 4 & 4 & 4 & 20 & 80 \\
\hline 10 & LCS & 3 & 3 & 3 & 3 & 4 & 16 & 64 \\
\hline 11 & FCM & 3 & 3 & 4 & 3 & 4 & 17 & 68 \\
\hline 12 & AT & 2 & 3 & 2 & 3 & 2 & 12 & 48 \\
\hline 13 & SF & 3 & 4 & 3 & 4 & 3 & 17 & 68 \\
\hline 14 & PAST & 4 & 4 & 4 & 4 & 4 & 20 & 80 \\
\hline 15 & AMVB & 4 & 4 & 4 & 5 & 4 & 21 & 84 \\
\hline 16 & YT & 2 & 2 & 2 & 3 & 3 & 12 & 48 \\
\hline 17 & PIK & 3 & 3 & 2 & 3 & 2 & 13 & 52 \\
\hline 18 & HM & 4 & 2 & 2 & 2 & 3 & 13 & 52 \\
\hline 19 & MT & 4 & 3 & 3 & 4 & 5 & 19 & 76 \\
\hline 20 & DE & 3 & 2 & 2 & 4 & 3 & 14 & 56 \\
\hline 21 & MT & 4 & 5 & 4 & 4 & 4 & 21 & 84 \\
\hline 22 & MYS & 4 & 5 & 4 & 4 & 4 & 21 & 84 \\
\hline 23 & YK & 4 & 4 & 4 & 4 & 4 & 20 & 80 \\
\hline 24 & JK & 4 & 4 & 4 & 5 & 4 & 21 & 84 \\
\hline 25 & VDSN & 4 & 4 & 5 & 5 & 4 & 22 & 88 \\
\hline 26 & YKN & 5 & 3 & 4 & 4 & 3 & 19 & 76 \\
\hline 27 & UDB & 2 & 2 & 3 & 2 & 3 & 12 & 48 \\
\hline 28 & FXWN & 4 & 4 & 3 & 4 & 3 & 18 & 72 \\
\hline 29 & B & 2 & 3 & 2 & 2 & 2 & 11 & 44 \\
\hline 30 & HAIF & 4 & 3 & 5 & 4 & 3 & 19 & 76 \\
\hline 31 & FU & 5 & 4 & 4 & 4 & 5 & 22 & 88 \\
\hline 32 & SCK & 4 & 4 & 3 & 4 & 3 & 18 & 72 \\
\hline 33 & MAL & 3 & 4 & 4 & 4 & 3 & 18 & 72 \\
\hline 34 & AOO & 4 & 4 & 4 & 4 & 4 & 20 & 80 \\
\hline 35 & ABID & 4 & 5 & 4 & 4 & 3 & 20 & 80 \\
\hline 36 & MEW & 4 & 4 & 3 & 4 & 3 & 18 & 72 \\
\hline 37 & STB & 3 & 4 & 4 & 4 & 4 & 19 & 76 \\
\hline 38 & GHF & 4 & 4 & 4 & 4 & 5 & 21 & 84 \\
\hline JUMLAH & 135 & 136 & 133 & 143 & 135 & 682 & 2728 \\
\hline RERATA & 3.6 & 3.6 & 3.5 & 3.8 & 3.8 & 18 & 72 \\
\hline & & & & & & & & \\
\hline 12 & & & 4 & 3 & 3 \\
\hline
\end{tabular}

Dilihat pada tabel tersebut rata-rata siswa kelas VIII SMP Maubeli memiliki kemampuan yang baik ketika diukur dengan aspek-aspek penilaian yang ditentukan. Secara keseluruhan rerata kemampuan siswa dalam menulis puisi berdasarkan kelima aspek penilaian tersebut mencapai nilai $72 \%$, dengan jumlah skor keseluruhan 2728 , dan termasuk dalam kategori baik.

Tabel 2. Hasil Penilaian Membaca Puisi

\begin{tabular}{|c|c|c|c|c|c|c|c|}
\hline \multirow{2}{*}{ NO } & \multirow{2}{*}{$\begin{array}{c}\text { Kode } \\
\text { Nama } \\
\text { Siswa }\end{array}$} & Artikulasi & $\begin{array}{c}\text { Gaya/ } \\
\text { Nada }\end{array}$ & Penghayatan & Penafsiran & Jumlah Skor & Nilai \\
\cline { 3 - 8 } & & Skor maks & $\begin{array}{c}\text { Skor } \\
\text { maks 5 }\end{array}$ & $\begin{array}{c}\text { Skor } \\
\text { maks 5 }\end{array}$ & $\begin{array}{c}\text { Skor } \\
\text { maks 5 }\end{array}$ & $\begin{array}{c}\text { Skor maks } \\
20\end{array}$ & $\begin{array}{c}\text { Nilai } \\
\text { maks 100 }\end{array}$ \\
\hline 1 & MWT & 4 & 4 & 4 & 4 & 16 & 80 \\
\hline 2 & WDB & 4 & 4 & 4 & 4 & 16 & 80 \\
\hline 3 & YEL & 4 & 4 & 5 & 3 & 16 & 80 \\
\hline 4 & EE & 4 & 3 & 3 & 3 & 12 & 60 \\
\hline 5 & N & 3 & 3 & 4 & 4 & 14 & 70 \\
\hline 6 & MVO & 4 & 4 & 3 & 4 & 15 & 75 \\
\hline
\end{tabular}




\begin{tabular}{|c|c|c|c|c|c|c|c|}
\hline 7 & AF & 3 & 3 & 3 & 4 & 13 & 65 \\
\hline 8 & DSD & 3 & 4 & 4 & 4 & 15 & 75 \\
\hline 9 & CIKA & 4 & 4 & 4 & 4 & 16 & 80 \\
\hline 10 & LCS & 3 & 3 & 3 & 4 & 13 & 65 \\
\hline 11 & FCM & 5 & 4 & 4 & 4 & 17 & 85 \\
\hline 12 & AT & 4 & 4 & 3 & 3 & 14 & 70 \\
\hline 13 & SF & 3 & 4 & 3 & 3 & 13 & 65 \\
\hline 14 & PAST & 4 & 4 & 4 & 4 & 16 & 80 \\
\hline 15 & AMVB & 4 & 4 & 4 & 5 & 17 & 85 \\
\hline 16 & YT & 3 & 2 & 3 & 3 & 11 & 55 \\
\hline 17 & PIK & 3 & 3 & 3 & 3 & 12 & 60 \\
\hline 18 & HM & 4 & 3 & 3 & 2 & 12 & 60 \\
\hline 19 & MT & 4 & 3 & 5 & 4 & 16 & 80 \\
\hline 20 & DE & 3 & 3 & 3 & 2 & 11 & 55 \\
\hline 21 & MT & 4 & 5 & 4 & 4 & 17 & 85 \\
\hline 22 & MYS & 5 & 3 & 4 & 4 & 16 & 80 \\
\hline 23 & YK & 4 & 4 & 4 & 4 & 16 & 80 \\
\hline 24 & JK & 5 & 4 & 4 & 4 & 17 & 80 \\
\hline 25 & VDSN & 4 & 4 & 4 & 3 & 15 & 75 \\
\hline 26 & YKN & 5 & 3 & 3 & 4 & 15 & 75 \\
\hline 27 & UDB & 3 & 2 & 3 & 2 & 10 & 50 \\
\hline 28 & FXWN & 4 & 4 & 4 & 4 & 16 & 80 \\
\hline 29 & B & 4 & 3 & 2 & 2 & 11 & 55 \\
\hline 30 & HAIF & 5 & 4 & 5 & 4 & 18 & 90 \\
\hline 31 & FU & 5 & 4 & 5 & 4 & 18 & 90 \\
\hline 32 & SCK & 5 & 4 & 3 & 4 & 16 & 80 \\
\hline 33 & MAL & 5 & 4 & 4 & 4 & 18 & 90 \\
\hline 34 & AOO & 5 & 4 & 4 & 3 & 16 & 80 \\
\hline 35 & ABID & 5 & 4 & 4 & 4 & 17 & 85 \\
\hline 36 & MEW & 5 & 4 & 3 & 3 & 15 & 75 \\
\hline 37 & STB & 4 & 4 & 4 & 3 & 15 & 75 \\
\hline 38 & GHF & 4 & 4 & 4 & 4 & 16 & 80 \\
\hline JUMLAH & 135 & 136 & 133 & 143 & 626 & 2830 \\
\hline RERATA & 3.6 & 3.6 & 3.5 & 3.8 & 18 & 74 \\
\hline & & & & & & & \\
\hline
\end{tabular}

Dilihat pada tabel tersebut rata-rata siswa kelas VIII SMP Maubeli memiliki kemampuan yang baik ketika diukur dengan aspek-aspek penilaian tersebut. Secara keseluruhan rerata kemampuan siswa dalam menulis puisi dengan pengamatan objek secara langsung berdasarkan kelima aspek penilaian tersebut mencapai nilai $74 \%$, dengan jumlah skor keseluruhan 2830, dan termasuk dalam kategori baik.

Tabel 3. Hasil Penilaian Menulis dan Membaca Puisi

\begin{tabular}{|c|c|c|c|c|}
\hline \multirow{2}{*}{ No } & \multirow{2}{*}{ Kode Nama Siswa } & \multicolumn{3}{|c|}{ Skor Penilaian } \\
\cline { 3 - 5 } & & $\begin{array}{c}\text { Menulis Puisi } \\
\text { Nilai }\end{array}$ & $\begin{array}{c}\text { Membaca Puisi } \\
\text { Nilai }\end{array}$ & $\begin{array}{c}\text { Jumlah } \\
\text { Nilai }\end{array}$ \\
\hline 1 & MWT & 84 & 80 & 82 \\
\hline 2 & WDB & 80 & 80 & 80 \\
\hline 3 & YEL & 76 & 80 & 78 \\
\hline 4 & EE & 68 & 60 & 64 \\
\hline 5 & N & 72 & 70 & 71 \\
\hline 6 & MVO & 76 & 75 & 75.5 \\
\hline
\end{tabular}




\begin{tabular}{|c|c|c|c|c|}
\hline 7 & $\mathrm{AF}$ & 64 & 65 & 64.5 \\
\hline 8 & DSD & 72 & 75 & 73.5 \\
\hline 9 & CIKA & 80 & 80 & 80 \\
\hline 10 & LCS & 64 & 65 & 64.5 \\
\hline 11 & FCM & 68 & 85 & 76.5 \\
\hline 12 & AT & 48 & 70 & 60 \\
\hline 13 & SF & 68 & 65 & 66.5 \\
\hline 14 & PAST & 80 & 80 & 80 \\
\hline 15 & AMVB & 84 & 85 & 84.5 \\
\hline 16 & YT & 48 & 55 & 51.5 \\
\hline 17 & PIK & 52 & 60 & 56 \\
\hline 18 & HM & 52 & 60 & 56 \\
\hline 19 & MT & 76 & 80 & 78 \\
\hline 20 & $\mathrm{DE}$ & 56 & 55 & 55.5 \\
\hline 21 & MT & 84 & 85 & 84.5 \\
\hline 22 & MYS & 84 & 80 & 82 \\
\hline 23 & $\mathrm{YK}$ & 80 & 80 & 80 \\
\hline 24 & JK & 84 & 80 & 82 \\
\hline 25 & VDSN & 88 & 75 & 81.5 \\
\hline 26 & YKN & 76 & 75 & 75.5 \\
\hline 27 & UDB & 48 & 50 & 49 \\
\hline 28 & FXWN & 72 & 80 & 76 \\
\hline 29 & B & 44 & 55 & 49.5 \\
\hline 30 & HAIF & 76 & 90 & 83 \\
\hline 31 & $\mathrm{FU}$ & 88 & 90 & 89 \\
\hline 32 & SCK & 72 & 80 & 76 \\
\hline 33 & MAL & 72 & 90 & 81 \\
\hline 34 & $\mathrm{AOO}$ & 80 & 80 & 80 \\
\hline 35 & ABID & 80 & 85 & 82.5 \\
\hline 36 & MEW & 72 & 75 & 73.5 \\
\hline 37 & STB & 76 & 75 & 75.5 \\
\hline 38 & GHF & 84 & 80 & 82 \\
\hline \multicolumn{2}{|r|}{ JUMLAH } & 2728 & 2830 & 2713.5 \\
\hline \multicolumn{2}{|r|}{ RERATA } & 72 & 74 & 71.5 \\
\hline
\end{tabular}

Berdasarkan tabel penilaian hasil karangan siswa di atas, terlihat jelas bahwa penilaian dalam pembelajaran mengapresiasi puisi dari hasil menulis dan membaca puisi tersebut menghasilkan rerata skor $71.5 \%$ dari jumlah keseluruhan yakni 2713.5. Dilihat pada tabel tersebut rata-rata siswa kelas VIII SMP Maubeli memiliki kemampuan mengapresiasi puisi dikategorikan baik. Artinya meskipun ada beberapa nilai siswa yang tidak memenuhi kriteria penilaian baik menulis maupun membaca, namun secara keseluruhan dapat diukur dan hasilnya memuaskan. Berikut tabel hasil perolehan dengan tingkat penguasaan siswa dalam menulis dan membaca puisi.

Tabel 4. Tingkat Penguasaan Siswa dalam Menulis dan Membaca Puisi

\begin{tabular}{|l|c|c|c|}
\hline \multicolumn{1}{|c|}{ Kategori } & Interval Skor Nilai & Jumlah Siswa & Presentase Tingkat penguasaan \\
\hline Baik Sekali & $80-100$ & 16 orang & $42.10 \%$ \\
\hline Baik & $70-79$ & 11 orang & $28.94 \%$ \\
\hline Cukup & $60-69$ & 5 orang & $13.15 \%$ \\
\hline Kurang & $0-59$ & 6 orang & $15.78 \%$ \\
\hline
\end{tabular}


Berdasarkan tabel tersebut, tingkat penguasaan siswa kelas VIII SMP Negeri Maubeli dalam menulis dan membaca puisi berinterval 80-100, dengan kategori baik sekali sebanyak 16 siswa sehingga persentase tingkat penguasaan hanya mencapai $42.10 \%$. Tingkat penguasaan siswa dalam mengapresiasi puisi berinterval 70-79 dengan kategori baik sebanyak 11 siswa sehingga persentase tingkat penguasaan mencapai 28.94\%. Tingkat penguasaan siswa dalam menulis dan membaca puisi, dengan interval 60-69 berkategori cukup baik sebanyak 5 siswa, sehingga persentase tingkat penguasaan mencapai $13.15 \%$. Tingkat penguasaan siswa dalam mengapresiasi puisi, dengan interval 0-59 berkategori kurang baik sebanyak 6 siswa, sehingga persentase tingkat penguasaan mencapai $15.78 \%$.

\section{SIMPULAN}

Kegiatan pengabdian berupa pelatihan menulis dan mengapresiasi puisi pada siswa SMP Negeri Maubeli Kefamenanu dapat diselenggarakan dengan baik dan berjalan lancar sesuai dengan rencana kegiatan, tujuan dan target luaran yang dihasilkan. Penerapan teknik mengamati objek secara langsung dalam pelatihan menulis dan mengapresiasi puisi merupakan salah satu teknik yang tepat terutama bagi penulis pemula seperti siswa SMP Negeri Maubeli. Kegiatan ini mendapat sambutan sangat baik terbukti dengan keaktifan dan intesnya siswa sampai berakhirnya kegiatan ini. Hasil dari kegiatan ini menunjukkan bahwa tingkat kemampuan dan penguasaan siswa dalam berkreasi menulis dan mengapresiasi (membaca) puisi terkategori baik. Kelanjutan kegiatan serupa dengan teknik yang berbeda dapat dilakukan oleh pengabdi-pengabdi lain.

\section{UCAPAN TERIMA KASIH}

Penulis mengucapkan terima kasih yang mendalam atas dukungan dan partisipasi dari berbagai pihak sampai terselesainya kegiatan ini. Di antaranya pihak sekolah dalam hal ini Kepala sekolah yang telah memeberi kesempatan untuk berbagi pengetahuan dan keterampilah kepada siswasiswanya; kepada para guru, terutama guru Bahasa Indonesia ( Ibu Lisa dan Ibu Benga Ola Yustina) dengan perannya masing-masing; terima kasih pula kepada siswa-siswa kelas IX smp Negeri Maubeli atas antusiasnya dalam berpartisipasi dan berperan aktif menyukseskan kegiatan pengabdian sampai selesai.

\section{DAFTAR PUSTAKA}

Arief, H. \& Sampara, J. 2019. Pengaruh Penggunaan Pendekatan Keterampilan Proses Dalam Meningkatkan Kemampuan Mengapresiasi Puisi Siswa Kelas Viii Di Smp 11 Kota Makassar. Algazali| International Journal Of Educational Research, 2(1):9-16.

Herman J. Waluyo. 2002. Apresiasi Puisi: Panduan untuk Pelajar dan Mahasiswa. Jakarta: Gramedia Pustaka Utama

Muchlisoh. 2003. Materi Pokok Pendidikan Bahasa Indonesia. Jakarta Departemen Pendidikan dan Kebudayaan.

Ristian, I. 2020. Peningkatan Kreativitas Mahasiswa Dalam Menulis Puisi Melalui Teknik Satu Peristiwa Satu Karya. Dinamika: Jurnal Bahasa, Sastra, Pembelajarannya, 3(1): $1-7$.

Zaidan, Abdul Rozak, dkk. 2001. Kamus Istilah Sastra. Jakarta: Balai Pustaka. 